\title{
CONTRASTANDO MARCAS DE ORALIDADE EM TRADUÇÕES DE “ALTA LITERATURA” E DE “BEST-SELLERS DE FICÇÃO POPULAR”: ERNEST HEMINGWAY E AGATHA CHRISTIE
}

\author{
CONTRASTING ORALITY MARKERS IN TRANSLATIONS OF \\ "HIGHBROW LITERATURE" AND "POPULAR BEST-SELLING FICTION": \\ ERNEST HEMINGWAY AND AGATHA CHRISTIE
}

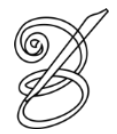 \\ Lauro Maia AMORIM \\ Universidade Estadual Paulista (UNESP) ${ }^{1}$
}

Resumo: Este artigo tem como objetivo oferecer uma análise quantitativa de marcas de oralidade em diálogos ficcionais em duas categorias de obras literárias: as associadas à chamada alta literatura e aquelas consideradas como best-sellers de ficção popular. Valendo-se do software AntConc, este estudo investigou a ocorrência de 45 tipos de marcas de oralidade envolvendo a variação linguística diafásica em dois grupos de obras literárias traduzidas para o português brasileiro: quatro obras traduzidas de Ernest Hemingway e outras quatro de Agatha Christie. A pesquisa visa a observar: a) a variedade de marcas de oralidade presentes nessas traduções; b) quais marcas de oralidade não foram empregadas, e c) se houve alguma marca geralmente não recomendada pela tradição gramatical conservadora. Os resultados sugerem certas regularidades e diferenças significativas entre os dois grupos de traduções sob análise, o que possibilitou a proposição de algumas hipóteses explicativas de natureza preliminar.

Palavras-chave: Estudos da Tradução. Marcas de oralidade. Alta literatura. Best-sellers.

Abstract: This article aims to offer a quantitative analysis of orality markers in fictional dialogues in two categories of literary works: those associated with highbrow literature and those considered to be bestselling popular fiction. By resorting to the AntConc software, this study investigated the occurrence of 45 types of orality markers regarding register or diaphasic linguistic variation in two different groups of literary works translated into Brazilian Portuguese: four translated books by Ernest Hemingway and four ones by Agatha Christie. The research was meant to observe: a) the variety of orality markers present in such translations; $b$ ) which orality markers were not employed, and c) if there was any orality marker usually not recommended by the traditional conservative grammar manuals. The results suggest possible regularities and significant differences between the two groups of translations under scrutiny, which allows for some preliminary explanatory hypotheses.

Keywords: Translation Studies. Orality markers. Highbrow literature. Best-sellers.

RECEBIDO EM: 10/04/2018

ACEITO EM: 09/05/2018

PUBLICADO EM: julho 2018

AMORIM. Contrastando marcas de oralidade em traduções de "alta literatura" e de "best-sellers de ficção popular": Ernest Hemingway e Agatha Christie

Belas Infiéis, v. 7, n. 1, p. 59-90, 2018. 


\section{Introdução}

proposta deste artigo é oferecer uma análise comparativa preliminar, fundada na
observação empírica e descritiva, da ocorrência de marcas de oralidade em falas de
diálogos ficcionais em duas categorias de obras literárias: as associadas à alta literatura e as que são consideradas best-sellers de ficção de popular. Investiga-se se seria possível observar diferenças quanto à distribuição das ocorrências de marcas de oralidade (ou ausência delas) nessas duas categorias de obras literárias. Na primeira parte, discute-se a diferença entre alta literatura e literatura de ficção popular, seguida da apresentação de Ernest Hemingway (Contos Volume 2) e Agatha Christie (Morte na Praia); em seguida, há uma introdução teórica sobre a variação diafásica e outras formas de variação linguística. Na última seção, a pesquisa apresenta um levantamento quantitativo, obtido por meio do software AntConc ${ }^{2}$, da ocorrência de 45 tipos de marcas de oralidade em dois grupos de obras: quatro obras de Ernest Hemingway: Contos volume 2 (traduzida por José J. Veiga), O sol também se levanta (traduzida por Berenice Xavier), Por quem os sinos dobram (traduzida por Luiz Peazê), e Do outro lado do rio, entre as árvores (traduzida por José Geraldo Vieira), todas publicadas 60 pela editora Record/Bertrand Brasil. No segundo grupo, analisaram-se quatro obras de Agatha Christie: Morte na Praia (traduzida por Rodrigo Breunig), Assassinato no Expresso Oriente (traduzida por Petrucia Finkler), Cai o pano (traduzida por Bruno Alexander), e Um punhado de centeio (traduzida por Alexandre Boide), todas publicadas pela editora L\&PM. A pesquisa visa a observar: a) a variedade de marcas de oralidade presentes nessas traduções; b) quais marcas de oralidade não foram empregadas, e c) se houve alguma marca de oralidade geralmente não recomendada pela tradição gramatical conservadora. Os resultados sugerem certas regularidades e diferenças significativas entre os dois grupos de traduções sob análise, o que possibilitou a proposição de algumas hipóteses explicativas de natureza preliminar.

\section{Alta literatura e best-sellers de ficção popular}

Obras originalmente produzidas em uma nação, ou "importadas" via tradução ou adaptação, podem ocupar "lugares" diferentes nas hierarquias culturais de um país. Os textos literários que, no Brasil, são publicados originalmente em português ou traduzidos de uma língua estrangeira, remetem a diferentes posições que seus autores e obras ocupam naquilo que Even-Zohar (2013) chama de polissistema literário. Esse polissistema representa conjuntos de repertórios literários que, em uma determinada cultura, se relacionam de maneira dinâmica, 
envolvendo hierarquizações segundo as quais certas obras, autores ou até mesmo gêneros se destacam como mais centrais em comparação a outros, possivelmente menos centrais ou até marginais:

\begin{abstract}
Segundo [Tynianov, 1921, 1923], na literatura, certas propriedades são canonizadas enquanto que outras permanecem não-canonizadas. A partir desse ponto de vista, por "canonizadas" entendemos aquelas normas e obras literárias (isso é, tanto modelos como textos) que nos círculos dominantes de uma cultura são aceitas como legítimas e cujos produtos mais marcantes são preservados pela comunidade para que formem parte de sua herança histórica. "Não-canonizadas" quer dizer, pelo contrário, aquelas normas e textos que esses círculos rejeitam como ilegítimas e cujos produtos, em longo prazo, a comunidade esquece frequentemente (a não ser que seu status mude). A canonicidade não é, portanto, uma característica inerente às atividades textuais a nível algum: não é um eufemismo para "boa literatura" frente à "má literatura". O fato de que em certos períodos certas características tendam a agrupar-se em torno a este ou aquele status não implica que tais características sejam "essencialmente" pertinentes a um status determinado. Obviamente, as próprias pessoas-na-cultura podem em um ou outro período conceber em tais termos estas distinções, mas ao historiador está permitido usá-las somente como prova do conjunto de normas de um período. (EVEN-ZOHAR, 2013, p. 7).
\end{abstract}

Romances de Machado de Assis, Guimarães Rosa e Clarice Lispector ocupam a categoria de obras canônicas da literatura brasileira: são autores amplamente estudados nas universidades. Contam com uma fortuna crítica expressa em livros, artigos de periódicos e ensaios publicados em revistas especializadas. Suas obras são comentadas e ensinadas nas escolas, constituindo-se de temas abordados em vestibulares. De modo semelhante, obras de autores como Shakespeare, James Joyce, Marcel Proust, Miguel de Cervantes ou Dante Alighieri ocupam um lugar de canonicidade inegável: além de serem objetos de pesquisa na academia, suas criações são consideradas obras clássicas da literatura internacional, na medida em que são não apenas traduzidas amplamente, para muitas línguas, mas são também retraduzidas ao longo do tempo de forma que sua presença é reforçada e reafirmada na memória coletiva.

É importante reconhecer, porém, que a abrangência desse processo de consolidação e reconhecimento no interior da alta literatura é variável: autores como Homero, Shakespeare, Miguel de Cervantes e Boccaccio são muito facilmente associados ao que chamamos de "clássicos"; o mesmo pode se dizer de autores como Virginia Woolf, Kafka ou Flaubert: guardadas as diferenças incomensuráveis entre si, hoje são vistos como "clássicos" da modernidade. Por outro lado, autores contemporâneos como Tony Morrison, Philip Roth ou Don Delillo, que são amplamente premiados e traduzidos, tendo suas obras reconhecidas pela 
crítica internacional e pela pesquisa acadêmica, acarretam um reconhecimento simbólico menos abrangente em comparação ao daqueles autores canônicos da literatura clássica mundial: ainda que pertencentes ao círculo da alta literatura, esses autores ainda estão por alcançar um espaço de maior consolidação que somente poderá ser produzido com o tempo e, principalmente, com a reafirmação discursivo-interpretativa que novas gerações de leitores, críticos e estudiosos poderão contribuir para a ampliação de sua permanência na memória coletiva associada aos cânones literários. De qualquer modo, todos esses autores e suas obras refletem, fundamentalmente, do ponto de vista sociológico, uma forma de prestígio que, em graus variados, encontra ressonância nas instituições jornalísticas de destaque, nos centros de ensino e pesquisa, na crítica especializada, bem como nas casas editoriais (que se interessam pela alta literatura), e em grupos de leitores que contribuem, direta ou indiretamente, para a atribuição de capital cultural e simbólico às obras literárias. Além disso, essas obras foram concebidas de acordo com determinados "códigos" de apreciação, segundo regras firmadas no interior da comunidade que produz e reproduz os limites que circunscrevem a aceitabilidade de um autor ou autora e sua obra no campo da cultura erudita.

No campo da indústria cultural, há obras e autores que, embora possam desfrutar de imenso sucesso junto aos leitores, não chegam a alcançar, de maneira sistemática e duradoura, um reconhecimento alicerçado pelas instituições que tradicionalmente legitimam o prestígio literário junto aos círculos de leitores, críticos e pesquisadores associados à difusão de obras da alta literatura e da cultura erudita. Autores como Sidney Sheldon, John Grisham, Danielle Steel e Stephenie Meyer, entre outros, são reconhecidos pelo sucesso estrondoso de vendas de seus livros, alavancado, com frequência, por adaptações fílmicas e televisivas de suas obras, o que garante um círculo de reconhecimento que está fundamentalmente amparado pelo mercado literário de entretenimento, sujeito a certas de regras de funcionamento relativos a sua produção e consumo, como aponta Sodré (1988), sendo a busca pela previsibilidade uma dessas regras. A previsibilidade se relaciona com a busca de fórmulas narrativas que permitam a garantia do sucesso, ou seja, que o livro possa ser adquirido pelo maior número de pessoas possível, e em um período de tempo relativamente curto. E nisso reside, também, a efemeridade do best-seller. Como aponta Prado Henrique (2010, p. 46-47):

Por o best-seller ser uma literatura popular ficcional, acaba tendo um período de duração muito curto nas prateleiras. Isto é, um livro entra no mercado, é apresentado ao público por meio de anúncios, de propagandas excessivas, de críticas positivas, mas, depois de determinado tempo, acaba entrando numa posição de saturação, 
principalmente, quando surge outro best-seller para tomar o seu lugar. [...] Por causa da efemeridade desse gênero e do constante problema relacionado às vendas, os autores de best-sellers correm o constantemente o risco do insucesso: virar imitadores do seu próprio trabalho. Para garantir as vendas, eles começam a repetir padrões que deram certo em romances anteriores, tanto seus quanto de outros colegas, ou seja, seguem as chamadas "fórmulas". ()

Ademais, tende-se a evitar, em um texto que se pretenda um best-seller, quaisquer experimentalismos que possam tornar o que se conta menos importante do que o modo como isso é contado, justamente para garantir o nível máximo possível de transparência linguística para os seus leitores, fundamentalmente atentos à trama e aos acontecimentos, e, possivelmente menos interessados pela forma como a linguagem (em sua autoreferencialidade) tornaria isso possível. Além disso, com frequência, os romances best-sellers são enquadrados de acordo com categorias editoriais gerais, uma vez que essas representam nichos que já demonstraram ter alcançado sucesso em atrair a atenção dos leitores: romance jurídico (John Grisham); romântico (Danielle Steel); de terror (Stephen King); de suspense (Dan Brown); policial (Agatha Christie); de fícção científica, e, nos últimos anos, os romances para "young adults", como Crepúsculo, de Stephenie Meyer e até Harry Potter, de J. K. Rowling. Em outras palavras, é desejável que um típico best-seller de entretenimento seja facilmente classificável de acordo com essas (ou outras) categorias (mesmo que seja uma combinação delas).

Obras associadas à alta literatura tenderiam a frustrar o leitor que busca, por exemplo, histórias que necessariamente apresentem um clímax bem definido e desejável, por vezes traduzido por um "final feliz" e que possam ainda oferecer uma moral de vida. Nessas obras é possível que não haja clímax algum, nem mesmo um "final feliz", garantindo a satisfação do leitor. Via de regra, os best-sellers de entretenimento não desfrutam do prestígio literário como aquele consagrado à alta literatura pelas instituições acadêmicas e de pesquisa, como as universidades, por exemplo. Isso não impede, porém, que a saga Harry Potter seja eventualmente utilizada como paradidáticos em escolas do ensino fundamental, e mesmo como objetos de estudo na universidade. Não é necessariamente incomum que dissertações sejam defendidas acerca das contribuições de best-sellers para além do puro entretenimento. É o caso do trabalho de Morais (2018), que analisa o questionamento do modelo de herói clássico em Jogos Vorazes, de Suzanne Collins.

Embora pesquisas com best-sellers sejam fundamentais, pois lançam luz sobre o funcionamento de obras pouco estudadas no universo acadêmico, é inegável que as diferenças nas regras de produção e consumo entre best-sellers e alta literatura fazem com que cada uma

AMORIM. Contrastando marcas de oralidade em traduções de "alta literatura" e de "best-sellers de ficção popular": Ernest Hemingway e Agatha Christie

Belas Infiéis, v. 7, n. 1, p. 59-90, 2018. 
dessas produções proporcione expectativas diferentes, a despeito do mérito ou da qualidade que certos best-sellers possam implicar. Não é mera casualidade o fato de que são estes que frequentemente ocupam as estantes mais visíveis na entrada das livrarias.

Ainda que, tanto no universo mercadológico editorial quanto no crítico-literário, se pratique uma distinção bastante clara (para a grande maioria dos casos) entre esses dois domínios, é em nome de uma certa relativização dessas diferenças que se argumentaria que a força mercadológica se estenderia sobre ambos domínios, já que o livro, seja ele da "alta literatura" ou um "best-seller de entretenimento popular", seria um produto cultural que se precifica no conjunto das relações econômicas que determinam a distribuição e classificação dos bens culturais.

Essa suposição não está incorreta, porque, embora represente um dado da realidade, ela, de fato, não anula a existência de dois campos diferentes, um erudito, e outro demarcado pela indústria cultural:

O sistema de produção e circulação de bens simbólicos define-se como o sistema de relações objetivas entre diferentes instâncias definidas pela função que cumprem na divisão do trabalho de produção, de reprodução e de difusão de bens simbólicos. $\mathrm{O}$ campo de produção propriamente dito deriva sua estrutura específica da oposição mais ou menos marcada conforme as esferas da vida intelectual e artística - que se estabelece entre, de um lado, o campo de produção erudita enquanto sistema que produz bens culturais (e os instrumentos de apropriação destes bens) objetivamente destinados (ao menos a curto prazo) a um público de produtores de bens culturais que também produzem para produtores de bens culturais e, de outro, o campo da indústria cultural especificamente organizado com vistas à produção de bens culturais destinados a não-produtores de bens culturais ("o grande público") que podem ser recrutados tanto nas frações não-intelectuais das classes dominantes ("o público cultivado") como nas demais classes sociais. Ao contrário do sistema da indústria cultural que obedece à lei da concorrência para a conquista do maior mercado possível, o campo da produção erudita tende a produzir ele mesmo suas normas de produção e os critérios de avaliação de seus produtos, e obedece à lei fundamental da concorrência pelo reconhecimento propriamente cultural concedido pelo grupo de pares que são, ao mesmo tempo, clientes privilegiados e concorrentes. É a partir deste princípio que se pode compreender não somente as relações entre o campo de produção erudita e o "grande público" e a representação que os intelectuais ou os artistas possuem desta relação, mas também o funcionamento do campo, a lógica de suas transformações, a estrutura das obras que produz e a lógica de sua sucessão. (BOURDIEU, 2011, p.105).

Se concordarmos com Bourdieu (2011), a diferença entre cultura erudita, nela incluída a alta literatura, e a indústria cultural, que abrange os best-sellers de entretenimento, não reside na suposição de que a cultura erudita não seja atravessada por regras econômicas de mercado, enquanto que a indústria cultural o seria. Ambos domínios são, de fato, acessíveis pelas mãos do mercado editorial. No entanto, as regras que tornam possível o reconhecimento e a 
consagração de uma obra ou autor junto à alta literatura (campo da cultura erudita) são erigidas no interior desse campo particular, e não fora dele. Em outras palavras, os recursos, os critérios, as análises que verificam a validade e a consagração de um autor ou autora no campo da cultura erudita respondem a um requisito fundamental: a busca e a garantia da autonomia da arte perante quaisquer outros fatores externos (sejam eles políticos, religiosos ou econômicos), excluindo, portanto, a necessidade de atender, em primeiro lugar, à demanda econômica que só seria, de fato, alcançada sistematicamente com a aprovação e consumo do grande público. De modo geral, esse grande público não integra, tipicamente, o círculo a que Bourdieu denomina de "produtores" da cultura erudita, no caso da alta literatura: artistas, escritores, poetas, críticos literários, pesquisadores universitários, instituições que conferem certos prêmios literários de grande prestígio, ou seja, que produzem o discurso de fundação e de validação do que é aceitável de acordo com determinados critérios estéticos definidos por essa comunidade. Isso, obviamente, não significa que a dimensão econômica esteja excluída: a cultura erudita se comercializa, até porque existe um público disposto a pagar mais por ela, mas segundo regras próprias que possam garantir que a comercialização de obras da alta literatura (ou de qualquer outro tipo de arte erudita) esteja dentro dos limites discursivos da autonomia artística de que nos fala Bourdieu (2011).

Isso explica porque uma mesma editora pode perfeitamente manter uma coleção de livros essencialmente voltada para a exposição de best-sellers de entretenimento popular, e uma outra com autores consagrados (ou em processo de consagração) associados à alta literatura. Em muitas situações, a editora apenas reproduz as regras de distinção já existentes, e que garantem, por um lado, uma produção literária erudita pautada na ideia da autonomia da arte e relativamente independente da demanda econômica como fonte geradora de sua criação, e, por outro, uma produção ficcional de entretenimento cuja qualidade será muito mais facilmente auferida no momento em que ela for capaz de alcançar o grande público, materializando, assim, seu sucesso em número de vendas. Portanto, a força motriz discursiva que organiza a criação literária no campo da indústria cultural não é aquela que se traduz pela busca e reafirmação, mesmo que inconscientes, da autonomia da arte literária, mas a capacidade de que todo projeto literário se torne um best-seller capaz de alcançar um número expressivo de leitores em prazos mais curtos. Essa força motriz dará forma ao tipo de projeto literário que se queira bemsucedido, tendo, portanto, que atender critérios de legibilidade, transparência e simplicidade no que diz respeito à linguagem, bem como ser classificável de acordo com determinadas

\footnotetext{
AMORIM. Contrastando marcas de oralidade em traduções de "alta literatura" e de "best-sellers de ficção popular": Ernest Hemingway e Agatha Christie Belas Infiéis, v. 7, n. 1, p. 59-90, 2018.
} 
categorias ("ficção policial", “de terror", “de suspense" etc.) que facilitem sua pronta identificação.

Para esta pesquisa, selecionaram-se dois autores que representam essas duas tendências distintas: Ernest Hemingway e Agatha Christie.

\subsection{Ernest Hemingway e Agatha Christie: diferenças na apresentação dos autores} em suas obras traduzidas no Brasil

Ernest Hemingway nasceu em 21 de julho de 1899 em Oak Park, nos Estados Unidos. O autor é uma das maiores referências da literatura norte-americana. Alistou-se como voluntário quando os Estados Unidos entraram na Primeira Guerra Mundial. Quando voltou ao seu país, trabalhou como repórter para jornais americanos e canadenses. $\mathrm{O}$ autor cobriu outros eventos de grande importância ao voltar à Europa, e todas as suas experiências o influenciaram muito na escrita de suas obras. Hemingway recebeu o Nobel de Literatura em 1954 e faleceu em 1961.

Pode-se depreender a diferença entre obras da alta literatura e best-sellers de entretenimento popular observando-se o modo com que os autores e suas obras são apresentadas em tradução. Comecemos com Contos - Volume 2, de Ernest Hemingway, coletânea publicada pela Bertrand Brasil, e traduzido por J. J. Veiga ${ }^{3}$. Na segunda orelha do livro, oferece-se a seguinte informação:

\footnotetext{
ERNEST HEMINGWAY é um dos pilares da literatura contemporânea mundial. Nascido em 1899, começou a escrever aos 18 anos para um jornal. Quando os Estados Unidos entraram na Primeira Guerra Mundial, alistou-se como voluntário, tornandose motorista de ambulância para o Exército da Itália. Após ser ferido, recebeu uma condecoração do governo italiano. Ao voltar para os Estados Unidos, trabalhou como repórter para jornais americanos e canadenses, e então voltou para Europa cobrindo eventos como a Revolução Grega. Durante os anos 1920, tornou-se membro do grupo de expatriados americanos em Paris, o qual ele escreveu em seu primeiro livro (1926). Ernest Hemingway foi agraciado com o Nobel de Literatura em 1954 e faleceu em 1961. (HEMINGWAY, 2015a, 2a orelha, itálicos meus).
}

Ernest Hemingway é um autor que conta, atualmente, com uma exposição mais do que consolidada no campo da cultura erudita e no subcampo da alta literatura. A Editora Bertrand confirma isso, ao chamar a atenção do leitor para a importância central da produção literária de Hemingway para a literatura contemporânea mundial. Destaca, também, a conquista do autor ao mais prestigiado prêmio internacional de literatura, o Prêmio Nobel. 
Essa breve exposição, que ilustra o prestígio de Hemingway como pertencente ao campo erudito da alta literatura, se contrasta com a natureza diferente do prestígio de que goza Agatha Christie. A autora é um dos grandes nomes da literatura best-seller. Escreveu inúmeros romances de mistério, contos, peças e poemas. Criou dois personagens que se tornaram mundialmente famosos: o detetive belga Hercule Poirot e Miss Jane Marple. Seus livros em inglês venderam mais de dois bilhões de exemplares e foram traduzidos para mais de 50 idiomas. Na $4^{\mathrm{a}}$ capa do livro Morte na Praia, publicado pela editora L\&PM, encontramos o seguinte dizer de um(a) crítico(a) do The Guardian: "seria demais considerar Agatha Christie uma das melhores escritoras contemporâneas?" (CHRISTIE, 2013, 4a capa). A questão é que embora Agatha Christie seja reconhecidamente uma das maiores escritoras de romance policial, ao lado de Arthur Conan Doyle, a pergunta suscitada pelo crítico se inicia com uma "dúvida" (da qual ele ou ela está disposto(a) a abrir mão) justamente porque sugerir que ela esteja entre as melhores escritoras contemporâneas implica possivelmente posicioná-la ao lado de autoras consagradas da alta literatura, grupo do qual Christie não faz parte. Mas ela integra uma tradição reconhecida, que, à esteira de Edgar Allan Poe (criador do gênero policial), e de Arthur Conan Doyle (criador das histórias de Sherlock Holmes), tem ensejado, definitivamente, uma memória coletiva prolongada por inúmeros sucessos de vendas. É uma memória coletiva construída, no entanto, no interior das relações editoriais e de leitura instaladas no campo da indústria cultural dos best-sellers.

\section{Marcas de oralidade em traduções literárias: a busca pela verossimilhança}

No campo dos Estudos da Tradução, o interesse pela variação linguística está entre os temas mais relevantes de pesquisa, especialmente quando se trata da tradução literária. Britto (2012), por exemplo, salienta a importância de se criar um efeito de verossimilhança na construção de falas e diálogos. O autor ressalta que esse efeito é conscientemente obtido através de recursos textuais, lembrando que a verossimilhança é a sugestão de algo que parece real, sem necessariamente o ser. Assim, deve-se entender que a produção de diálogos verossímeis não significa a tentativa de se transcrever todos os dados de uma fala real, já que esta é repleta de detalhes, incluindo repetições, interrupções, ênfases, frases incompletas, redundâncias e lacunas que inviabilizariam a representação aceitável e legível da fala em textos literários. Assim é que as marcas de oralidade serviriam ao propósito de se criar um efeito de verossimilhança, ou seja, a ilusão de que uma fala literária seria real.

\footnotetext{
AMORIM. Contrastando marcas de oralidade em traduções de "alta literatura" e de "best-sellers de ficção popular": Ernest Hemingway e Agatha Christie Belas Infiéis, v. 7, n. 1, p. 59-90, 2018.
} 
Pode-se fazer a distinção entre dois aspectos: variantes linguísticas não padrão consideradas estigmatizadas (como A gente fomos pra casa) e variantes linguísticas que, embora do ponto de vista de certos compêndios gramaticais normativos sejam tidas como não padrão, não chegam a ser, de fato, estigmatizadas, na prática linguística diária, como, por exemplo, "Encontre ela!".

Considerem-se os exemplos abaixo (os destaques são meus):

a) Trecho do livro Native Son, do consagrado escritor afro-americano Richard Wright (1940/1966), traduzido por Aurora Soares Neiva (Filho Nativo, 1995):

“Jack, yuh mean t'stan' there ' $n$ ' say yuh'd give tha' nigger up t' the white folks?”
“Damn right Ah would!” (p. 235)
— Jack, tu tá dizeno que tinha corage de dedurá aquele criolo pros branco?
- Craro que tinha. (p. 518)

b) Trechos do livro Indignation, de Philip Roth (2008), traduzido por Jorio Dauster (ROTH, 2013):

"You can't believe what some of those women will put you through before they buy their chicken," he told me. And then he would mimic them: " "Turn it over. No, over. Let me see the bottom." (p. 05)

"Você não acredita o que algumas dessas mulheres te obrigam a fazer antes de comprar uma galinha", ele explicava. E aí as imitava: "Vira ela. Não, pro outro lado. Deixa eu ver a parte de trás". (p. 14)

“Knock it off, Bert," said one of the other boys. "Shut up and let him go to sleep." (p. 24)

"Para com isso, Bert", disse um dos outros rapazes. Cala a boca e deixa ele ir dormir." (p. 27)

Quando se observa a tradução de Aurora Neiva, pode-se notar a intersecção de três fatores: ${ }^{4}$ a variação diastrática (que indica a classe social mais baixa dos falantes e baixa escolaridade) torna-se proeminente, ocorrendo, também, numa situação de maior informalidade e intimidade entre falantes (variação diafásica), com aspectos linguísticos que sugerem uma variação linguística diatópica regional (“tu tá..," é comum, por exemplo, entre falantes cariocas - a própria tradutora é carioca). Na tradução de Jório Dauster, a representação da variação diafásica é mais proeminente do que as outras formas de variação, sendo mais sugestiva de um contexto de informalidade do que da suposta ausência de escolaridade dos falantes.

AMORIM. Contrastando marcas de oralidade em traduções de "alta literatura" e de "best-sellers de ficção popular": Ernest Hemingway e Agatha Christie

Belas Infiéis, v. 7, n. 1, p. 59-90, 2018. 
O emprego de marcas de oralidade não estigmatizadas em traduções revela a existência de um "transbordamento" entre a fala culta e a escrita culta. Embora a fala culta seja menos conservadora que a escrita, esta será permeável, de algum modo, às influências das inovações que são produzidas na fala culta, "mesmo que [essas inovações sejam] continuamente condenadas por certos comentadores gramaticais" (FARACO, 2009, p.54). Um exemplo disso são as chamadas orações relativas cortadoras. Na fala culta brasileira é comum a omissão da preposição antecedendo o pronome relativo, sendo mais frequente que se diga "este é o livro que mais gostei" do que "este é o livro de que mais gostei". Faraco (2009) chama a atenção para o fato de que frases com relativas cortadoras são comuns não apenas em programas televisivos envolvendo debates, como o Roda Viva, da TV Cultura, mas também em textos da grande imprensa, como já demonstrou Bagno (2010), ainda que sejam consideradas inadequadas de acordo com o que prescreve a norma padrão.

\section{Levantamento quantitativo de 45 tipos de marcas de oralidade em quatro obras de}

\section{Ernest Hemingway e em quatro de Agatha Christie}

Abaixo, recorremos à quantificação das marcas de oralidade em dois grupos de obras dos autores aqui analisados, o que permitirá avaliar, de maneira mais ampla, a distribuição dessas marcas e a média referente à diversidade de tipos de marcas que essas obras podem ou não apresentar.

Tabela 1. Quatro traduções de obras de Ernest Hemingway

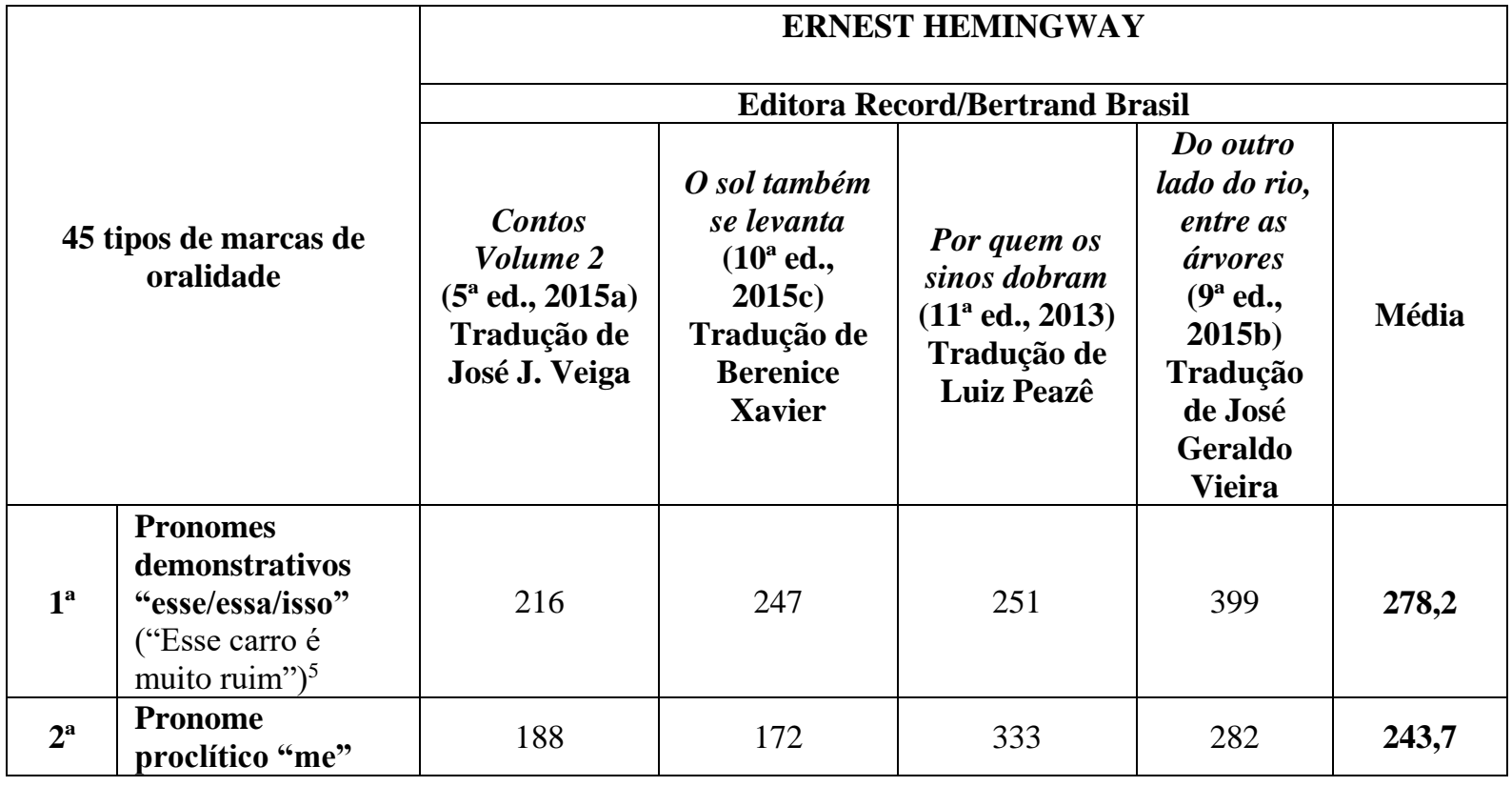

AMORIM. Contrastando marcas de oralidade em traduções de "alta literatura" e de "best-sellers de ficção popular": Ernest Hemingway e Agatha Christie Belas Infiéis, v. 7, n. 1, p. 59-90, 2018. 


\begin{tabular}{|c|c|c|c|c|c|c|}
\hline & $\begin{array}{l}\text { ("Ele me disse } \\
\text { isso") }\end{array}$ & & & & & \\
\hline $3^{a}$ & $\begin{array}{l}\text { Formas verbais } \\
\text { sintáticas } \\
\text { analíticas } \\
\text { ("Eu vou comprar } \\
\text { isso") }\end{array}$ & 59 & 61 & 131 & 85 & 84 \\
\hline $4^{a}$ & $\begin{array}{l}\text { Pronome } \\
\text { proclítico "te" } \\
\text { ("Quero te dizer") } \\
\text { algo") }\end{array}$ & 1 & $\varnothing$ & $232^{6}$ & 2 & $\mathbf{5 8 , 7 5}$ \\
\hline $5^{a}$ & $\begin{array}{l}\text { "Num"/ "Numa" } \\
\text { ("Entrou numa } \\
\text { fria") }\end{array}$ & 23 & 23 & 99 & 77 & 55,5 \\
\hline $6^{a}$ & $\begin{array}{l}\text { Pronome } \\
\text { possessivo } \\
\text { "dele(s)/dela(s)" } \\
\text { ("A casa dele é a da } \\
\text { direita") }\end{array}$ & 50 & 36 & 63 & 34 & 45,7 \\
\hline $7^{\mathrm{a}}$ & $\begin{array}{l}\text { Substantivos, } \\
\text { advérbios e } \\
\text { adjetivos no } \\
\text { diminutivo } \\
\text { ("baixinho, } \\
\text { devagarinho") } \\
\end{array}$ & 23 & 10 & 72 & 20 & 31,2 \\
\hline $8^{\mathbf{a}}$ & $\begin{array}{l}\text { Imperativo no } \\
\text { modo indicativo } \\
\text { (“Fecha essa } \\
\text { porta!") }\end{array}$ & 7 & 1 & 82 & $\varnothing$ & 22,5 \\
\hline $9^{a}$ & $\begin{array}{l}\text { Verbo "ter" no } \\
\text { sentido de "haver" } \\
\text { impessoal } \\
\text { ("Tem muita gente } \\
\text { com medo") }\end{array}$ & 13 & 1 & 63 & 1 & 19,5 \\
\hline $10^{\mathrm{a}}$ & $\begin{array}{l}\text { Ter que... } \\
\text { ("Nós temos que } \\
\text { vencer") }\end{array}$ & 7 & $\varnothing$ & 58 & 10 & 18,7 \\
\hline $11^{\mathrm{a}}$ & $\begin{array}{l}\text { "Que/é que" após } \\
\text { pronome } \\
\text { interrogativo } \\
\text { ("O que é que você } \\
\text { tem?") }\end{array}$ & 50 & 1 & 1 & 18 & 17,5 \\
\hline $12^{\mathrm{a}}$ & $\begin{array}{l}\text { Pronome "você" } \\
\text { com função de } \\
\text { objeto verbal } \\
\text { não } \\
\text { preposicionado } \\
\text { ("Não quero você } \\
\text { aqui") }\end{array}$ & 29 & 3 & 17 & 18 & 16,75 \\
\hline $13^{\mathrm{a}}$ & $\begin{array}{l}\text { Tinha }(\mathbf{m})+ \\
\text { particípio verbal } \\
\text { ("Ela tinha vendido } \\
\text { tudo") }\end{array}$ & 5 & 10 & 41 & 10 & 16,5 \\
\hline $14^{\mathrm{a}}$ & $\begin{array}{l}\text { Pronome "a } \\
\text { gente" com função } \\
\text { de sujeito }\end{array}$ & 5 & 6 & 16 & 24 & 12,7 \\
\hline
\end{tabular}

AMORIM. Contrastando marcas de oralidade em traduções de "alta literatura" e de "best-sellers de ficção popular": Ernest Hemingway e Agatha Christie

Belas Infiéis, v. 7, n. 1, p. 59-90, 2018. 


\begin{tabular}{|c|c|c|c|c|c|c|}
\hline & $\begin{array}{l}\text { (“A gente sabe } \\
\text { tudo") }\end{array}$ & & & & & \\
\hline $15^{\mathrm{a}}$ & $\begin{array}{l}\text { Ir para (em vez de } \\
\text { "ir à") } \\
\text { ("Fomos para Nova } \\
\text { Iorque no ano } \\
\text { seguinte") }\end{array}$ & 14 & 8 & 14 & 12 & 12 \\
\hline $16^{\mathrm{a}}$ & $\begin{array}{l}\text { Verbo + pronome } \\
\text { sujeito ele(s)/ela(s) } \\
\text { com função de } \\
\text { objeto verbal } \\
\text { ("Pega ele logo!") }\end{array}$ & 22 & $\varnothing$ & 10 & 1 & 8,25 \\
\hline $17^{\mathrm{a}}$ & $\begin{array}{l}\text { "Aí”" (marcador } \\
\text { discursivo) } \\
\text { (“Aí disseram que } \\
\text { não sabiam nada...") }\end{array}$ & $\varnothing$ & 1 & 20 & $\varnothing$ & 5,25 \\
\hline $18^{\mathrm{a}}$ & $\begin{array}{l}\text { "Pra" } \\
\text { ("Quero isso pra } \\
\text { ontem") }\end{array}$ & 15 & $\varnothing$ & 4 & 1 & 5 \\
\hline $19^{a}$ & $\begin{array}{l}\text { Pronome "você" } \\
\text { com função de } \\
\text { objeto verbal } \\
\text { preposicionado ("a } \\
\text { você" - quando é } \\
\text { tradicionalmente } \\
\text { substituído por } \\
\text { "Ihe") } \\
\text { ("Quero dar o } \\
\text { dinheiro a você") }\end{array}$ & 2 & 3 & 4 & 11 & 5 \\
\hline $20^{a}$ & $\begin{array}{l}\text { Verbo + pronome } \\
\text { eu/ele(s)/ela(s) com } \\
\text { função de sujeito } \\
\text { de } \\
\text { encaixada oração } \\
\text { ("Não vou deixar } \\
\text { ela te magoar") }\end{array}$ & 4 & $\varnothing$ & 10 & 3 & 4,25 \\
\hline $21^{a}$ & $\begin{array}{l}\text { Mescla de "você" } \\
\text { + "te" } \\
\text { ("Você sabe que te } \\
\text { amo") }\end{array}$ & $\varnothing$ & $\varnothing$ & 14 & $\varnothing$ & 3,5 \\
\hline $22^{\mathrm{a}}$ & $\begin{array}{l}\text { "Dum"/“duma" } \\
\text { ("Isso é duma } \\
\text { empresa de São } \\
\text { Paulo") }\end{array}$ & 1 & $\varnothing$ & 2 & 10 & 3,25 \\
\hline $23^{a}$ & $\begin{array}{l}\text { Emprego de } \\
\text { pronomes } \\
\text { possessivos antes } \\
\text { de vocativos } \\
\text { ("Seu canalha"!) }\end{array}$ & 6 & $\varnothing$ & 3 & 3 & 3 \\
\hline $24^{a}$ & $\begin{array}{l}\text { Onde é/foi que...? } \\
\text { (“Onde é que ele } \\
\text { está escondido?") }\end{array}$ & 8 & 1 & $\varnothing$ & 1 & 2,5 \\
\hline $25^{\mathrm{a}}$ & $\begin{array}{l}\text { "Quem sabe” } \\
\text { ("Quem sabe a } \\
\text { gente arranja } \\
\text { dinheiro?") }\end{array}$ & 2 & 2 & 1 & 4 & 2,25 \\
\hline
\end{tabular}

AMORIM. Contrastando marcas de oralidade em traduções de "alta literatura" e de "best-sellers de ficção popular": Ernest Hemingway e Agatha Christie Belas Infiéis, v. 7, n. 1, p. 59-90, 2018. 


\begin{tabular}{|c|c|c|c|c|c|c|}
\hline $26^{\mathrm{a}}$ & $\begin{array}{l}\text { Se (Condicional) + } \\
\text { pretérito } \\
\text { imperfeito } \\
\text { (“Se eu fosse rico, } \\
\text { comprava um } \\
\text { barco") }\end{array}$ & 2 & $\varnothing$ & $\varnothing$ & 2 & 2 \\
\hline $27^{\mathrm{a}}$ & $\begin{array}{l}\text { "Que nem" } \\
\text { ("Ele vive que nem } \\
\text { um louco") }\end{array}$ & $\varnothing$ & $\varnothing$ & $\varnothing$ & 7 & ,75 \\
\hline $28^{\mathrm{a}}$ & $\begin{array}{l}\text { "Dar para" e } \\
\text { variantes } \\
\text { ("Não dá para } \\
\text { pagar"/"Não deu } \\
\text { pra ir") }\end{array}$ & 1 & $\varnothing$ & 5 & 1 & 1,75 \\
\hline $29^{a}$ & $\begin{array}{l}\text { Pronome "a } \\
\text { gente" com função } \\
\text { de objeto verbal } \\
\text { ("Ele viu a gente") }\end{array}$ & 3 & $\varnothing$ & 3 & 1 & 1,75 \\
\hline $30^{\mathrm{a}}$ & $\begin{array}{l}\text { Artigo + Nome } \\
\text { próprio } \\
\text { ("O John sabia de } \\
\text { tudo") }\end{array}$ & 2 & $\varnothing$ & $\varnothing$ & 4 & 1,5 \\
\hline $31^{\mathrm{a}}$ & $\begin{array}{l}\text { Regências } \\
\text { proscritas pela } \\
\text { norma padrão } \\
\text { tradicional } \\
\text { ("Agradei o Paulo } \\
\text { com um presente"; } \\
\text { "Não perdoo a } \\
\text { Maria"; "Vou pagar } \\
\text { ele com cheque") }\end{array}$ & 1 & $\varnothing$ & 2 & 1 & 1 \\
\hline $32^{\mathrm{a}}$ & $\begin{array}{l}\text { "Vai ver (que)" } \\
\text { ("Vai ver tudo isso } \\
\text { não vale nada") }\end{array}$ & $\varnothing$ & $\varnothing$ & 3 & $\varnothing$ & 0,75 \\
\hline $33^{\mathrm{a}}$ & $\begin{array}{l}\text { "De repente" } \\
\text { ("De repente você } \\
\text { até pode viajar") }\end{array}$ & 1 & $\varnothing$ & $\varnothing$ & 2 & $\mathbf{0 , 7 5}$ \\
\hline $34^{\mathrm{a}}$. & $\begin{array}{l}\text { "Quem (me) dera" } \\
\text { ("- Vai viajar? } \\
\text { - Quem me m!") } \\
\text { dera! }\end{array}$ & 3 & $\varnothing$ & $\varnothing$ & $\varnothing$ & 0,75 \\
\hline $35^{\mathrm{a}}$ & $\begin{array}{l}\text { Regência nominal } \\
\text { não canônica (com } \\
\text { queísmo) } \\
\text { ("Eu tenho certeza } \\
\text { que ela voltará") }\end{array}$ & 2 & $\varnothing$ & 1 & $\varnothing$ & $\mathbf{0 , 7 5}$ \\
\hline $36^{a}$ & $\begin{array}{l}\text { Dupla negativa } \\
\text { ("Eu não vou, não") }\end{array}$ & 2 & $\varnothing$ & 1 & $\varnothing$ & 0,75 \\
\hline $37^{\mathrm{a}}$ & $\begin{array}{l}\text { "Cadê" } \\
\text { ("Cadê a bolsa?") }\end{array}$ & 1 & $\varnothing$ & $\varnothing$ & $\varnothing$ & 0,25 \\
\hline $38^{\mathrm{a}}$ & $\begin{array}{l}\text { "Vai que" } \\
\text { ("Vai que não dá } \\
\text { certo") }\end{array}$ & 1 & $\varnothing$ & $\varnothing$ & $\varnothing$ & 0,25 \\
\hline $39^{\mathrm{a}}$ & $\begin{array}{l}\text { "Tá" } \\
\text { ("Tá tudo bem?") }\end{array}$ & 1 & $\varnothing$ & $\varnothing$ & $\varnothing$ & 0,25 \\
\hline
\end{tabular}

AMORIM. Contrastando marcas de oralidade em traduções de "alta literatura" e de "best-sellers de ficção popular": Ernest Hemingway e Agatha Christie

Belas Infiéis, v. 7, n. 1, p. 59-90, 2018. 


\begin{tabular}{|c|c|c|c|c|c|c|}
\hline $40^{\mathrm{a} 7}$ & 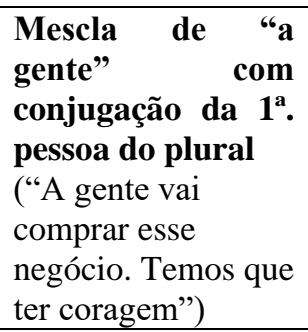 & 1 & $\varnothing$ & $\varnothing$ & $\varnothing$ & 0,25 \\
\hline \multicolumn{2}{|c|}{$\begin{array}{l}\text { Número de tipos de } \\
\text { marcas de oralidade } \\
\text { empregados }\end{array}$} & 36 & 17 & 30 & 29 & 28 \\
\hline
\end{tabular}

Tabela 2. Quatro traduções de obras de Agatha Christie

\begin{tabular}{|c|c|c|c|c|c|c|}
\hline \multirow{3}{*}{\multicolumn{2}{|c|}{\begin{tabular}{|c|}
45 tipos de marcas de \\
oralidade
\end{tabular}}} & \multirow{2}{*}{\multicolumn{5}{|c|}{$\begin{array}{c}\text { AGATHA CHRISTIE } \\
\text { Editora L\&PM }\end{array}$}} \\
\hline & & & & & & \\
\hline & & $\begin{array}{c}\text { Morte na Praia } \\
\text { (2013) } \\
\text { Tradução de } \\
\text { Rodrigo } \\
\text { Breunig }\end{array}$ & \multirow{2}{*}{$\begin{array}{c}\text { Assassinato no } \\
\text { Expresso } \\
\text { Oriente } \\
\text { (2017) } \\
\text { Tradução de } \\
\text { Petrucia } \\
\text { Finkler } \\
\\
253\end{array}$} & \multirow{2}{*}{$\begin{array}{c}\text { Cai o pano } \\
\text { (2015) } \\
\text { Tradução de } \\
\text { Bruno } \\
\text { Alexander } \\
\\
133\end{array}$} & \multirow{2}{*}{$\begin{array}{c}\text { Um punhado } \\
\text { de centeio } \\
\text { (2014) } \\
\text { Tradução de } \\
\text { Alexandre } \\
\text { Boide } \\
\\
\\
\end{array}$} & \multirow{2}{*}{$\begin{array}{l}\text { Média } \\
295,25\end{array}$} \\
\hline $\mathbf{1}^{\mathbf{a}}$ & $\begin{array}{l}\text { Pronomes } \\
\text { demonstrativos } \\
\text { "esse/essa/isso" } \\
\text { ("Esse carro é } \\
\text { muito ruim") }\end{array}$ & 415 & & & & \\
\hline $2^{\mathrm{a}}$ & $\begin{array}{l}\text { Pronome } \\
\text { proclítico "me" } \\
\text { ("Ele me disse } \\
\text { isso") }\end{array}$ & 196 & 185 & 103 & 204 & 172 \\
\hline $3^{a}$ & $\begin{array}{l}\text { Pronome } \\
\text { possessivo } \\
\text { "dele(s)/dela(s)" } \\
\text { ("a casa dele é a } \\
\text { da direita") }\end{array}$ & 150 & 110 & 42 & 110 & 103 \\
\hline $4^{a}$ & $\begin{array}{l}\text { Substantivos, } \\
\text { advérbios e } \\
\text { adjetivos no } \\
\text { diminutivo } \\
\text { ("baixinho, } \\
\text { devagarinho") } \\
\end{array}$ & 27 & 33 & 17 & 100 & 44,25 \\
\hline $5^{a}$ & $\begin{array}{l}\text { Formas verbais } \\
\text { sintáticas } \\
\text { analíticas } \\
\text { ("Eu vou comprar } \\
\text { isso") }\end{array}$ & 18 & 39 & 26 & 51 & 33,5 \\
\hline $6^{a}$ & $\begin{array}{l}\text { Tinha }(\mathbf{m})+ \\
\text { particípio verbal } \\
\text { ("Ela tinha } \\
\text { vendido tudo") }\end{array}$ & 86 & $\varnothing$ & 13 & 29 & 32 \\
\hline $7^{\mathbf{a}}$ & "Num"/ "Numa" & 75 & 4 & 24 & 1 & 26 \\
\hline
\end{tabular}

AMORIM. Contrastando marcas de oralidade em traduções de "alta literatura" e de "best-sellers de ficção popular": Ernest Hemingway e Agatha Christie Belas Infiéis, v. 7, n. 1, p. 59-90, 2018. 


\begin{tabular}{|c|c|c|c|c|c|c|}
\hline & $\begin{array}{l}\text { (“Entrou numa } \\
\text { fria") }\end{array}$ & & & & & \\
\hline $8^{\mathbf{a}}$ & $\begin{array}{l}\text { "Aí" (marcador } \\
\text { discursivo) } \\
\text { (“Aí disseram que } \\
\text { não sabiam...") }\end{array}$ & 23 & $\varnothing$ & 6 & $\varnothing$ & 7,25 \\
\hline $9^{\mathbf{a}}$ & $\begin{array}{l}\text { "Que/é que" } \\
\text { após pronome } \\
\text { interrogativo } \\
\text { ("O que é que } \\
\text { você tem?") }\end{array}$ & 21 & $\varnothing$ & $\varnothing$ & $\varnothing$ & 5,25 \\
\hline $10^{\mathrm{a}}$ & $\begin{array}{l}\text { "Dar para" e } \\
\text { variantes } \\
\text { ("Não dá para } \\
\text { pagar"/ "Não deu } \\
\text { pra ir") }\end{array}$ & 3 & 4 & 4 & 12 & 5,75 \\
\hline $11^{\mathrm{a}}$ & $\begin{array}{l}\text { Ir para (em vez } \\
\text { de "ir à") } \\
\text { ("Fomos para } \\
\text { Nova Iorque no } \\
\text { ano seguinte") }\end{array}$ & 4 & 5 & 4 & 2 & 3,75 \\
\hline $12^{\mathrm{a}}$ & $\begin{array}{l}\text { "Quem sabe" } \\
\text { ("Quem sabe a } \\
\text { gente arranja } \\
\text { dinheiro?") }\end{array}$ & 1 & 10 & $\varnothing$ & 2 & 3,25 \\
\hline $13^{\mathrm{a}}$ & $\begin{array}{l}\text { Pronome "você" } \\
\text { com função de } \\
\text { objeto verbal } \\
\text { não } \\
\text { preposicionado } \\
\text { ("Não quero você } \\
\text { aqui") }\end{array}$ & 5 & 1 & 1 & 6 & 3,25 \\
\hline $14^{\mathrm{a}}$ & $\begin{array}{l}\text { Verbo "ter" no } \\
\text { sentido de } \\
\text { "haver" } \\
\text { impessoal } \\
\text { ("Tem muita } \\
\text { gente com } \\
\text { medo") }\end{array}$ & 1 & 1 & $\varnothing$ & 10 & 3 \\
\hline $15^{\mathrm{a}}$ & $\begin{array}{l}\text { Pronome "a } \\
\text { gente" com } \\
\text { função de sujeito } \\
\text { ("A gente sabe } \\
\text { tudo") }\end{array}$ & 6 & 5 & $\varnothing$ & $\varnothing$ & 2,75 \\
\hline $16^{\mathrm{a}}$ & $\begin{array}{l}\text { Artigo + Nome } \\
\text { próprio } \\
\text { ("O John sabia de } \\
\text { tudo") }\end{array}$ & $\varnothing$ & $\varnothing$ & 6 & 2 & 2 \\
\hline $17^{\mathrm{a}}$ & $\begin{array}{l}\text { Ter que... } \\
\text { ("Nós temos que } \\
\text { vencer") }\end{array}$ & 1 & $\varnothing$ & 3 & 3 & 1,75 \\
\hline $18^{\mathrm{a}}$ & $\begin{array}{l}\text { Imperativo no } \\
\text { modo indicativo } \\
\text { ("Fecha essa } \\
\text { porta!") }\end{array}$ & 2 & 5 & $\varnothing$ & $\varnothing$ & 1,75 \\
\hline $19^{\mathrm{a}}$ & "Né?" & $\varnothing$ & $\varnothing$ & $\varnothing$ & 5 & 1,25 \\
\hline
\end{tabular}

AMORIM. Contrastando marcas de oralidade em traduções de "alta literatura" e de "best-sellers de ficção popular": Ernest Hemingway e Agatha Christie

Belas Infiéis, v. 7, n. 1, p. 59-90, 2018. 


\begin{tabular}{|c|c|c|c|c|c|c|}
\hline & $\begin{array}{l}\text { (“Você não vai, } \\
\text { né?") }\end{array}$ & & & & & \\
\hline $20^{a}$ & $\begin{array}{l}\text { "De repente" } \\
\text { ("De repente você } \\
\text { até pode viajar") }\end{array}$ & $\varnothing$ & $\varnothing$ & $\varnothing$ & 4 & 1 \\
\hline $21^{\mathrm{a}}$ & $\begin{array}{l}\text { "Cadê" } \\
\text { ("Cadê a bolsa?") }\end{array}$ & $\varnothing$ & $\varnothing$ & 4 & $\varnothing$ & 1 \\
\hline $22^{\mathrm{a}}$ & $\begin{array}{l}\text { Emprego de } \\
\text { pronomes } \\
\text { possessivos antes } \\
\text { de vocativos } \\
\text { ("Seu canalha"!) }\end{array}$ & 1 & $\varnothing$ & $\varnothing$ & 3 & 1 \\
\hline $23^{a}$ & $\begin{array}{l}\text { Regência } \\
\text { nominal não } \\
\text { canônica (com } \\
\text { queísmo) } \\
\text { ("Eu tenho } \\
\text { certeza que ela } \\
\text { voltará") }\end{array}$ & 1 & $\varnothing$ & 2 & $\varnothing$ & 0,75 \\
\hline $24^{a}$ & $\begin{array}{l}\text { Verbo }+ \\
\text { pronome sujeito } \\
\text { ele(s)/ela(s) com } \\
\text { função de objeto } \\
\text { verbal } \\
\text { ("Pega ele logo!") }\end{array}$ & 2 & $\varnothing$ & $\varnothing$ & $\varnothing$ & 0,5 \\
\hline $25^{\mathrm{a}}$ & $\begin{array}{l}\text { Dupla negativa } \\
\text { ("Eu não vou, } \\
\text { não") }\end{array}$ & $\varnothing$ & $\varnothing$ & $\varnothing$ & 2 & 0,5 \\
\hline $26^{\mathrm{a}}$ & $\begin{array}{l}\text { Onde é/foi } \\
\text { que...? } \\
\text { “(Onde é que ele } \\
\text { está escondido?”) }\end{array}$ & $\varnothing$ & 1 & $\varnothing$ & 1 & 0,5 \\
\hline $27^{a}$ & $\begin{array}{l}\text { "Pra" } \\
\text { ("Quero isso pra } \\
\text { ontem") }\end{array}$ & $\varnothing$ & 1 & $\varnothing$ & $\varnothing$ & 0,25 \\
\hline $28^{a}$ & $\begin{array}{l}\text { "Que nem" } \\
\text { ("Ele vive que } \\
\text { nem um louco") }\end{array}$ & $\varnothing$ & $\varnothing$ & 1 & $\varnothing$ & 0,25 \\
\hline $29^{a}$ & $\begin{array}{l}\text { Regências } \\
\text { proscritas pela } \\
\text { norma padrão } \\
\text { tradicional } \\
\text { ("Agradei o Paulo } \\
\text { com um } \\
\text { presente"; "Não } \\
\text { perdoo a Maria"; } \\
\text { "Vou pagar ele } \\
\text { com cheque") } \\
\end{array}$ & 1 & $\varnothing$ & $\varnothing$ & $\varnothing$ & 0,25 \\
\hline $30^{\mathrm{a} 8}$ & $\begin{array}{l}\text { Pronome "a } \\
\text { gente" com } \\
\text { função de objeto } \\
\text { verbal } \\
\text { ("Ele viu a } \\
\text { gente") }\end{array}$ & 1 & $\varnothing$ & $\varnothing$ & $\varnothing$ & 0,25 \\
\hline \multicolumn{2}{|c|}{$\begin{array}{l}\text { Número de tipos de } \\
\text { marcas de oralidade } \\
\text { empregados }\end{array}$} & 22 & 15 & 16 & 19 & 18 \\
\hline
\end{tabular}

AMORIM. Contrastando marcas de oralidade em traduções de "alta literatura" e de "best-sellers de ficção popular": Ernest Hemingway e Agatha Christie Belas Infiéis, v. 7, n. 1, p. 59-90, 2018. 


\subsection{Observações sobre as tabelas 1 e 2 (obras de Hemingway e de Agatha Christie):}

\section{a) As primeiras dez posições nas duas tabelas:}

Ao observarmos os dez primeiros tipos de marcas de oralidade com maior média de ocorrência nos dois grupos de livros traduzidos, destacam-se as seguintes marcas de oralidade presentes em ambos os grupos de livros:

Os pronomes demonstrativos "esse", "essa" e "isso", em vez de "este", "esta" e "isto", tendem a prevalecer nas interações orais (BAGNO, 2010), o que acaba por se refletir no discurso escrito, como em "E essa camisa pouco vale agora" (HEMINGWAY, 2015a, p.244). O mesmo ocorrendo com o pronome "me" em posição proclítica, que representa a tendência da língua portuguesa falada no Brasil, em vez da forma pronominal enclítica, como em "aquilo me causou uma impressão muito forte" (CHRISTIE, 2014, p. 73). As construções verbais em formas analíticas, como em "Eu não ia suportar" (HEMINGWAY, 2015c, p. 28) também se destacam (em contraste com as construções sintéticas consideradas mais formais tais como "suportaria"), bem como o emprego de pronomes possessivos como "dele" ou "dela", no lugar de "seu" ou "sua", para se referir à terceira pessoa do discurso, como em "Qual é a explicação dele?" (CHRISTIE, 2013, p.165). E se revelou, também, como muito produtivo, sobretudo nas obras de Christie, o uso de substantivos, adjetivos e advérbios com formas diminutivas, como em "E como é que aquele rapaz bonzinho aguenta ser secretário [...]” (CHRISTIE, 2017, p.28). Ressalta-se, ainda, o emprego de "que/é que" após pronome interrogativo", como em "O que é que eu estava dizendo mesmo?" (HEMINGWAY, 2015b, p. 325).

Como os livros de Hemingway são volumosos, com entre 300 e 500 páginas em média, e os de Christie giram em torno de 250 páginas, é possível que se argumente que o emprego numericamente mais alto de certas marcas de oralidade deve-se, também, pelo menos parcialmente, ao fato de um livro possivelmente ter mais espaço para diálogos ${ }^{9}$. Entretanto, isso não impediu, por exemplo, que a média de ocorrência de pronomes demonstrativos "esse/essa/isso" nos livros de Christie fosse maior que a média ocorrida nos livros de Hemingway (295,25 contra 278,2, respectivamente). Outro exemplo é a média de 103 ocorrências de pronomes "dele/dela" nas obras de Christie, contra 45,7 nos livros de Hemingway. A despeito dessa observação, é notável o fato de que os dez primeiros tipos de marcas de oralidade, no grupo de livros de Hemingway, apresentam médias contendo, ao menos, duas casas decimais (como entre 84 e 17,5, $3^{\mathrm{a}}$ e $10^{\mathrm{a}}$ posições, respectivamente), 
estendendo-se até a $14^{\mathrm{a}}$ posição (média 12), ao passo que no grupo de livros de Agatha Christie, as médias com duas casas decimais se estendem até a $7^{\mathrm{a}}$ posição apenas (com média 26), caindo drasticamente para uma casa decimal $(7,25)$ já na $8^{a}$ posição (ocorrências de “aí"). Assim, já é possível notar uma extensão maior de médias com duas casas decimais para os 14 primeiros tipos de marcas nas obras de Hemingway, quando comparadas à extensão mais limitada de duas casas decimais apenas nas primeiras sete posições encontradas nos livros de Agatha Christie. Isso sugere que as marcas de oralidade ocupam, numericamente, um espaço mais limitado nos livros de Agatha Christie.

Um dado interessante é que, dentre as dez primeiras posições, no caso das traduções de Hemingway, a ocorrência de "verbo ter com sentido de haver impessoal", na $8^{a}$ posição, é o único tipo de marca de oralidade (entre as dez primeiras) que geralmente poderia atrair alguma forma de avaliação negativa, fundada nos compêndios gramaticais conservadores que tenderiam a privilegiar apenas o verbo haver com o sentido de impessoalidade. Comparativamente, quando se observam as dez primeiras posições no grupo de livros de Agatha Christie, não há nenhum tipo de marca de oralidade que, em contraste como o verbo "ter" com sentido de "haver", atraia algum posicionamento crítico mais conservador.

\section{b) Marcas de oralidade inexistentes nas obras de Hemingway e nas de Agatha Christie:}

Em uma primeira observação, nota-se que, nas quatro obras de Ernest Hemingway, se fazem ausentes 05 tipos de marcas de oralidade, enquanto que nos quatro livros de Agatha Christie estão ausentes 15 tipos. Vejamos as marcas de oralidade ausentes nos dois grupos de obras:

Grupo de livros de Hemingway: "Pro"; "né?"; "igualzinho a"; "tipo"; contração de "de" + "ele/ela" ou "de" + "o/a".

Grupo de livros de Christie: "Pro"; "tá"; "dum"/“duma"; "vai ver (que)"; "vai que"; "igualzinho a"; "quem (me) dera"; "tipo"; pronome proclítico "te"; mescla de "você" + "te"; contração de "de" + "ele/ela" ou "de" + "o/a"; pronome "você" com função de objeto verbal preposicionado; verbo + pronome ele(s)/ela(s) com função de sujeito de oração encaixada; mescla de "a gente" com conjugação da $1^{\text {a }}$ pessoa do plural; se $($ condicional $)+$ pretérito imperfeito. 
Parece evidente que certas marcas fonéticas são evitadas, como é o caso de "pro" (contração de "para o"), cujo emprego acentua o grau de informalidade de uma fala. "Tipo" (ou “tipo assim") é uma marca de oralidade geralmente utilizada para traduzir "like", como em "She's, like, kind of forgetful", oração que pode ser traduzida como "Ela é, tipo (assim), meio esquecida." Como apontam Dória e Alves (2014, p. 262), “o item lexical tipo vem se desprendendo de seu estatuto nominal de origem, passando por um processo de deslexicalização, assumindo traços gramaticais e pragmáticos, levando-se em conta também, sua agregação, em certos contextos, ao advérbio de modo assim". Tipicamente associado ao discurso de jovens e adolescentes, esse emprego do vocábulo "tipo" (ou "tipo assim"), embora venha sendo incorporado até mesmo no discurso de adultos e mesmo na escrita, sempre foi visto com certo grau de estigmatização, como apontam as autoras (cf. DÓRIA e ALVES, 2014, p. 271), o que pode explicar que seja uma marca de oralidade evitada nas traduções analisadas. Uma marca de oralidade que pode atrair, para si, alguma rejeição é a contração de "de" e "ele(s)/ela(s)" ou "de" e "o(s)/a(s)", como em "o fato deles serem felizes...." ou "apesar do país ter se endividado..." Segundo Bagno (2010, p. 135), essas construções já são encontradas em

78 textos escritos, inclusive em jornais de prestígio, como o Estado de São Paulo. Não foram, porém, encontradas em nenhum dos grupos de textos traduzidos analisados neste trabalho.

Ressalta-se, porém, que, nos livros de Agatha Christie, evitou-se o emprego de marcas de oralidade que foram utilizadas, se não em todas, pelo menos em algumas das traduções de Hemingway. Construções linguísticas tais como: "Não deixe ele começar novamente" (HEMINGWAY, 2013, p.192), envolvendo emprego de pronome tônico com função de oblíquo e de sujeito da oração seguinte; "[...] A polícia disse pra gente vir, então viemos. (HEMINGWAY, 2015 a , p. 337)", exibindo mescla de "a gente" com verbo conjugado em $1^{\text {a }}$ pessoa do plural, e "Se fosse Belmonte que fizesse isso, a multidão enlouquecia". (HEMINGWAY, 2015a, p. 174), caso em que há combinação de oração condicional com "se" acompanhada de pretérito imperfeito (em vez de futuro do pretérito, como requer a norma padrão). Embora essas marcas de oralidade sejam amplamente utilizadas na linguagem oral, sendo formas excelentes de representação da oralidade na escrita, elas não aparecem nos livros de Agatha Christie. 


\section{c) Variedade de tipos de marcas de oralidade empregada nos dois grupos de traduções}

Observa-se que a média que representa a variedade de ocorrências ${ }^{10}$ de marcas de oralidade nas traduções das quatro obras de Hemingway é de $\mathbf{2 8}$, enquanto que essa média, nas traduções das quatro obras de Christie, é de 18. Assim, pode-se concluir que, nas obras de Hemingway, há uma variedade maior de tipos de marcas de oralidade comparativamente à variedade apresentada nos livros de Christie.

Há uma diferença notável entre a maior e a menor presença de tipos de marcas de oralidade entre, pelo menos, duas obras de Hemingway (36 e 17), e uma diferença menos contrastante entre as obras de Agatha Christie em relação ao mesmo quesito (22 e 15). Isso parece sugerir que as traduções de Agatha Christie são relativamente mais homogêneas ou mais semelhantes entre si no que concerne à variedade de tipos de marcas de oralidade presentes nas quatro obras, enquanto que, no caso das traduções de Hemingway, os contrastes são maiores. Há uma maior heterogeneidade no emprego de diferentes tipos de marcas de oralidade nos textos de Hemingway, com exceção da tradução de Berenice Xavier (17 tipos de marcas, um valor numérico muito próximo da média geral para os livros de Agatha Christie, que é de 18).

Vale observar que a tradução de Berenice Xavier foi feita, originalmente, em 1966, e publicada pela editora Civilização Brasileira, atualmente um selo da Editora Record. A obra $O$ sol também se levanta passou a ser publicada pela Bertrand Brasil, também pertencente à Record. Isso explicaria, em parte, o teor mais formal de sua tradução, já que quanto mais antiga é uma tradução, maior é a probabilidade de que ela seja mais conservadora do ponto de vista da representação da oralidade na escrita ${ }^{11}$. Sublinha-se também que José J. Veiga, além de tradutor, foi um escritor premiado, inclusive com o Prêmio Jabuti, tendo escrito vários livros em que podemos observar a frequência com que o escritor recorre a marcas de oralidade para compor os diálogos de seus personagens ${ }^{12}$. É possível que a posição discursiva de escritor reconhecido, no caso de José J. Veiga, possa explicar, em parte, porque Contos Volume 2 se destaca, em comparação às demais traduções de Hemingway, como contendo o maior número de variedades de marcas de oralidade. Essa condição pode ter conferido, ao tradutor, maior visibilidade, de modo que sua tradução pode ter sido menos sistematicamente revisada, favorecendo-se, assim, formas linguísticas quase sempre desabonadas pela norma padrão estrita.

\footnotetext{
AMORIM. Contrastando marcas de oralidade em traduções de "alta literatura" e de "best-sellers de ficção popular": Ernest Hemingway e Agatha Christie Belas Infiéis, v. 7, n. 1, p. 59-90, 2018.
} 


\section{d) Observações sobre alguns contrastes no emprego de certas marcas de oralidade}

Dentre as 45 marcas de oralidade pesquisadas, algumas delas suscitam contrastes interessantes quando se comparam os resultados obtidos para os dois grupos de traduções. Abaixo destacam-se essas marcas de oralidade seguidas de suas respectivas médias em cada grupo de tradução:

\begin{tabular}{|c|c|c|}
\hline Marca de oralidade & $\begin{array}{c}\text { Ernest Hemingway } \\
\text { Grupo de traduções } \\
\text { (Bertrand Brasil) } \\
\text { Média }\end{array}$ & $\begin{array}{c}\text { Agatha Christie } \\
\text { Grupo de traduções } \\
\text { (L\&PM) } \\
\text { Média }\end{array}$ \\
\hline $\begin{array}{c}\text { Verbo "ter" com sentido } \\
\text { de "haver impessoal" }\end{array}$ & 19,5 & 3,0 \\
\hline $\begin{array}{c}\text { Imperativo no modo } \\
\text { indicativo }\end{array}$ & 22,5 & 1,75 \\
\hline $\begin{array}{c}\text { Verbo + pronome sujeito } \\
\text { "ele(s)"/ "ela(s)" com } \\
\text { função de objeto verbal }\end{array}$ & 8,25 & 0,5 \\
\hline $\begin{array}{c}\text { Verbo + pronome sujeito } \\
\text { "eu"/"ele(s)"/ "ela(s)" } \\
\text { com função de objeto } \\
\text { verbal e de sujeito de } \\
\text { oração encaixada }\end{array}$ & 4,25 & 0 \\
\hline $\begin{array}{c}\text { Regências proscritas pela } \\
\text { norma padrão tradicional }\end{array}$ & 1 & 0,25 \\
\hline Mescla de "você" e "te" & 3,5 & 0 \\
\hline
\end{tabular}

Essas marcas de oralidade foram destacadas porque, de modo geral, com exceção, em menor grau, do imperativo no indicativo, as demais expressões linguísticas não são recomendadas por grande parte dos manuais gramaticais normativos que prescrevem as formas linguísticas consideradas "cultas" pela tradição gramatical conservadora. Nesse sentido, as traduções da L\&PM estão visivelmente mais alinhadas a essa tradição, sendo, portanto, menos ousadas no que diz respeito ao emprego dessas marcas de oralidade.

\section{Considerações finais e algumas hipóteses}

O levantamento quantitativo proporcionou uma visão mais ampla acerca das traduções de duas categorias de obras literárias: as associadas à alta literatura (quatro traduções das obras de Ernest Hemingway) e aquelas classificadas como ficções de entretenimento popular (caso das quatro traduções das obras de Agatha Christie). Com base nos resultados obtidos e discutidos na seção anterior, é possível concluir que há uma diferença sensível na distribuição do emprego das marcas de oralidade nos dois grupos de traduções: chama a atenção o fato de 
que a média que representa a variedade empregada de tipos de marcas de oralidade nas traduções de Hemingway (Editora Bertrand Brasil/Record) é maior que a variedade observada nas traduções das obras de Agatha Christie (Editora L\&PM).

O que se pode fazer, com base nos resultados obtidos aqui, é ensaiar algumas hipóteses e refletir, contrastivamente, sobre outras informações relevantes não observadas neste trabalho. Deve-se considerar, por exemplo, que a editora L\&PM, detentora dos direitos de publicação das obras de Agatha Christie no Brasil, tem, em seu catálogo, duas traduções que são dignas de nota no que concerne à representação da variação linguística no texto traduzido. Millor Fernandes é o tradutor da peça Pigmaleão, obra de George Bernard Shaw: Millor Fernandes busca recriar a variedade inglesa cockney com o emprego de formas estigmatizadas da língua portuguesa $^{13}$. O segundo exemplo é a tradução, também publicada pela L\&PM, e feita por Rosaura Eichenberg, da obra Huckleberry Finn, de Mark Twain: Eichenberg busca recriar algumas das variedades linguísticas do sul dos Estados Unidos com formas linguísticas estigmatizadas da língua portuguesa ${ }^{14}$. Esses dois exemplos demonstram que a editora, possivelmente ao lado de outras, como é o caso da editora Companhia das Letras ${ }^{15}$, estejam implementando normas mais inovadoras no sistema literário brasileiro ${ }^{16}$, como já sugerido por Britto e Landsberg $(2015)^{17}$, acerca de uma maior abertura para as marcas de oralidade em traduções literárias.

Ocorre que essa abertura à representação da variação linguística, por parte da L\&PM, em relação a Pigmaleão e Huckleberry Finn, envolve dois aspectos fundamentais. Em primeiro lugar, é importante lembrar que esses textos são obras canônicas celebradas junto à literatura inglesa e à norte-americana, respectivamente. Ou seja, são obras que fazem parte do que aqui chamamos de alta literatura, guardadas, obviamente, as diferenças estéticas, linguísticas e mesmo políticas que as duas obras implicam. Esses dois exemplos, até certo ponto, portanto, se somam aos resultados obtidos nessa pesquisa quanto à representação da variação nas traduções de Hemingway, cujas obras também se associam à alta literatura. É possível que a condição de obras literárias associadas à alta literatura possa ter fomentado, ao lado de outros fatores, o florescimento, nas últimas décadas, de normas tradutológicas favoráveis à representação da variação, até porque, especialmente no caso das celebradas obras de Bernard Shaw (2005) e de Mark Twain (2011), há um reconhecimento tácito de que a representação da variação linguística nos textos originais não é apenas de inegável importância, mas sobretudo é um tema de clara visibilidade, atestada pela crítica especializada. Assim, visualiza-se um segundo aspecto que

AMORIM. Contrastando marcas de oralidade em traduções de "alta literatura" e de "best-sellers de ficção popular": Ernest Hemingway e Agatha Christie Belas Infiéis, v. 7, n. 1, p. 59-90, 2018. 
pode ter favorecido essa representação, pela L\&PM, nas obras de Shaw e Twain: o fato de que são variações linguísticas de natureza diatópica/regional e diastrática/social claramente dispostas no texto original como algo destacável do restante das falas, mormente escritas de acordo com formas linguísticas não estigmatizadas. Assim, há uma diferença notável entre discursos não estigmatizados (na maior parte dos diálogos), por um lado, e falas estigmatizadas e localizadas, de outro. Em outras palavras, não traduzir, ou, pelo menos, não tentar traduzir ou recriar essas variedades linguísticas estigmatizadas seria, numa visão mais atual, incorrer em um silenciamento de elementos estéticos visíveis nessas obras, o que certamente poderia atrair posicionamentos não favoráveis pela crítica especializada (geralmente alicerçada nos fundamentos discursivos que sustentam a circulação de produtos da cultura erudita, como discutido anteriormente).

Nossa hipótese, no entanto, é de que este último fator não seria a lógica que estaria em jogo quando se trata de tradução da variação diafásica. A variação diafásica envolve as diferenças linguísticas derivadas do registro formal ou informal. Ocorre que, como bem nos lembra Britto (2012), a distância entre o registro informal escrito e o propriamente falado não

82 é tão grande quando se tratam de diálogos ficcionais escritos em língua inglesa. É caso do exemplo (já visto anteriormente) extraído do romance de Philip Roth: “Turn it over. No, over. Let me see the bottom" (ROTH, 2013, p. 05). A fala em si é próxima da oralidade (num contexto em que uma cliente está dando uma ordem ao açougueiro para virar o frango para observar melhor o produto ela que pretende comprar). Essa fala, tal como escrita na ficção, não é muito diferente do que seria dito numa situação real, de oralidade em língua inglesa. Por envolver uma variação diafásica de natureza informal, não exibindo diferenças acentuadas de classe social (diastráticas) nem de ordem geográfica (diatópicas), não há, no trecho em inglês, nada que se destaque visivelmente das demais falas de outros personagens do romance de Roth (diferentemente do que ocorre nas obras de Shaw e Twain, com elementos linguísticos visivelmente estigmatizados).

A inexistência de marcas mais visíveis, no inglês, justamente por envolver predominantemente a variação diafásica, pode levar o tradutor, e mesmo o editor (sem muita consciência sociolinguística), a se aterem a formas linguísticas, na tradução, mais linhadas à formalidade e até às regras ditadas pela tradição gramatical normativa, sob pena de possivelmente atraírem críticas pautadas no argumento (certamente problemático) de que não 
haveria, visivelmente, no original, desvios que justifiquem o uso de formas linguísticas mais próximas da oralidade. ${ }^{18}$

Em resumo, levantaríamos duas hipóteses específicas:

1) O favorecimento da tradução de variedades linguísticas diatópicas (geográficas) e diastráticas (sociais) - por vezes com marcas de oralidade estigmatizadas — em textos ficcionais traduzidos, como no caso das traduções da L\&PM das obras de Bernard Shaw e Mark Twain, poderia estar condicionado à presença de elementos linguísticos em destaque (e em contraste com as demais falas) e que, associada a obras canônicas, de prestígio ou consideradas como oriundas da alta literatura, acentuaria, pelo menos na atualidade ${ }^{19}$, a demanda por sua recriação na tradução (em vista da própria crítica especializada que dá ou não aval a projetos literários — incluindo traduções — que balizem a qualidade de obras consagradas ou em processo de consagração). Seria uma forma de norma tradutória que, aos poucos, vai se firmando e se tornando uma referência cuja hegemonia, no Brasil, estaria sendo construída aos poucos;

2) A tradução que implique a representação da variação diafásica (com marcas de oralidade não estigmatizadas no plano da oralidade), pode não ter o mesmo grau $^{20} \mathrm{de}$ favorecimento, no Brasil atual, que se observa com as variedades linguísticas diastráticas. Isso pode ser muito claramente visto no caso das traduções das obras de Agatha Christie, publicadas pela mesma editora que favoreceu mais abertamente a tradução das variedades linguísticas diatópicas e diastráticas das obras de Shaw e Twain. Parece-nos que as normas tradutológicas que subjazem à tradução de Agatha Christie são outras: diferentemente do que ocorre com as traduções de Shaw e Twain, nos textos de Christie não há a presença de marcas linguísticas estigmatizadas que se destaquem visivelmente diante de outras falas; por outro lado, ainda que o emprego de marcas de oralidade não estigmatizadas (variedades diafásicas) proporcione uma melhor verossimilhança entre ficção (escrita) e realidade (oral), essas marcas suscitam uma ambiguidade interessante e até "perigosa"21.

Alguém poderia se perguntar: como é possível que, nas traduções de textos ficcionais, marcas linguísticas estigmatizadas nas práticas orais estariam sendo mais facilmente "aceitas" (vide traduções de Shaw e Twain/L\&PM) do que as marcas de oralidade amplamente não estigmatizadas nas produções orais (vide traduções de Agatha Christie/L\&PM)? Na medida em que as marcas de oralidade estigmatizadas (na maioria das vezes envolvendo variedades linguísticas diastráticas/de classe social) se destacam graficamente das demais falas, constrói- 
se um limite, uma fronteira clara entre o "português supostamente errado", possivelmente visto de forma cômica (e atribuível a certos personagens apenas), do restante das falas da narrativa (provavelmente alinhadas com a "correção" exigida pela tradição linguística normativa). Existe aí uma redoma de proteção que garante um lugar "seguro" para o não transbordamento das formas linguísticas estigmatizadas (tanto é que é muito difícil observar uma obra literária inteiramente escrita nessas formas linguísticas). Parece ser mais "fácil" aceitar que certos personagens falem de um modo diferente, e desviante, em certos momentos, do que concordar que isso se prolongue por toda a narrativa.

Se a variação diafásica for levada a sério em sua representação na escrita tradutória, a grande maioria das falas, em uma obra de ficção, acabaria sendo norteada pela busca de certa coerência que permita o seu uso mais sistemático. Embora não sejam de fato discriminadas ou estigmatizadas nas práticas orais (tais como “encontra ela!” ou "a gente se gosta, mas não vamos ficar juntos", ou "apesar dele ser rico, ele não gasta muito"), essas formas linguísticas diafásicas ainda podem atrair alguma rejeição, especialmente porque estão representadas $n a$ escrita (que tende, a ser vista, equivocadamente, como necessariamente mais formal e 84 conservadora). Seguindo a busca por essa coerência, as variedades linguísticas diafásicas teriam de ser marcadas em várias falas ao longo da narrativa, especialmente naquelas em que o contexto informal é implícito ou explícito, e mesmo em situações em que, ainda que não seja possível julgar se de fato há informalidade, o uso de marcas de oralidade dessa natureza poderia ser plenamente justificável em nome da verossimilhança linguística.

Nesse ponto, fica claro que não há um limite claro que contenha a expressão das marcas diafásicas - elas podem se estender para várias ou até mesmo para a maioria das falas dos diálogos. A ausência desse limite claro é algo que as próprias pesquisas com o Projeto NURC demonstraram (cf. PRETI, 1999, p. 23), quando os pesquisadores notaram que falantes ditos cultos (com ensino superior) em conversações, algumas das quais envolvendo entrevistas formais, faziam uso de marcas de oralidade que os estudiosos da gramática normativa tradicional sistematicamente condenam. Ou seja, a norma culta, que de fato é produzida por falantes cultos (em situações de informalidade e mesmo de maior monitoramento) é permeada por formas linguísticas orais.

A questão é que, no caso das traduções de Hemingway, a média que caracteriza a variedade de marcas de oralidade e a variação diafásica é bem mais representativa e os números apresentados demonstram que houve uma abertura mais sistemática, por parte dos tradutores ${ }^{22}$ 
e da Bertrand Brasil, a essa variação nas obras analisadas, diferentemente do que ocorreu com as traduções das obras de Agatha Christie, publicadas pela L\&PM. A hipótese de leitura que propomos, e que, naturalmente, terá de ser verificada em outras pesquisas com novos dados, é que talvez a tradução de obras literárias associadas à alta literatura e ao cânone literário erudito, pelo menos no que diz respeito às últimas décadas, possa ser mais permeável à variação diafásica (tanto quanto à diastrática), ao passo que best-sellers de ficção popular poderiam ser menos permeáveis.

Se concordarmos com Bourdieu (2011) que os agentes da cultura erudita (e da alta literatura, por extensão) promoveriam a autonomia do discurso artístico (literário, no caso) perante outras forças que lhe seriam externas (como o poder econômico em si mesmo), isso poderia, em tese, criar as condições ideais para o favorecimento tanto da representação de formas linguísticas estigmatizadas (geralmente envolvendo variação diastrática), e mais limitadas a certas falas que se destacam no texto, quanto de formas linguísticas associadas à variação diafásica, geralmente menos estigmatizadas ${ }^{23}$, e possivelmente aplicadas à maior parte dos diálogos.

A crença na autonomia da produção artística não exclui os fatores econômicos. $\mathrm{O}$ interesse econômico pela vendagem dessas obras seria atravessado pela ideia de que seus leitores também possam fazer parte do circuito de produção e consumo de obras eruditas, sendo, portanto, exigentes com relação a uma certa qualidade presumida e imaginada acerca do que se espera da tradução dessas obras (geralmente canonizadas, em processo de canonização, ou de autores contemporâneos consagrados ou promissores). E, certamente, a representação, no texto traduzido, da variação diafásica permitindo a construção de diálogos ficcionais mais verossímeis poderia estar competindo, atualmente, de maneira positiva, para a percepção dessa qualidade presumida, a despeito de forças que, vistas como "externas", passariam a ter um papel secundário, como, por exemplo, a percepção - equivocada ou não — de que o emprego dessas formas linguísticas poderia criar algum obstáculo à transparência e fluência do texto, supostamente garantidas com opções linguísticas que suscitem menos polêmica e que sejam mais previsíveis em relação ao que tradicionalmente se espera da modalidade escrita da língua.

Esses fatores que seriam, atualmente, secundários na produção de traduções de obras da alta literatura, passariam a ser muito mais importantes na tradução de best-sellers de ficção popular, justamente porque essas obras não fariam parte do circuito de produção literária erudita, não seriam norteadas pelo princípio de autonomia artística, mas, pelo contrário, por

\footnotetext{
AMORIM. Contrastando marcas de oralidade em traduções de "alta literatura" e de "best-sellers de ficção popular": Ernest Hemingway e Agatha Christie Belas Infiéis, v. 7, n. 1, p. 59-90, 2018.
} 
preceitos econômicos mais imediatos, e que poderiam interferir, de maneira mais efetiva, na limitação da permeabilidade que essas obras ofereceriam à variação diafásica, tal como os resultados acerca das traduções dos livros de Agatha Christie parecem demonstrar. Assim, é possível que a crença na autonomia literária das obras da alta literatura torne, em geral, a preocupação com a "transparência" da leitura uma questão de menor importância, o que favoreceria, atualmente, a possibilidade de maiores experimentações no campo da representação sociolinguística no texto literário traduzido (o que as três traduções de Hemingway parecem sugerir) ${ }^{24}$. Mas quando já não se acredita que essa autonomia esteja valendo (como no caso dos best-sellers), até porque ela não poderia existir em pleno direito se o que está em jogo, no caso, é a dependência primordial do fator econômico mais imediato, então a representação sistemática e ampla da variação linguística, no texto traduzido, pode se tornar um obstáculo, em vista da imagem que tradutores e editores constroem acerca de seu leitor ideal: ansioso pelo que se conta (o que importa é a trama, a história) e menos por como isso é contado (a relação entre linguagem e sua verossimilhança com o real torna-se secundária).

Essas hipóteses são apenas ensaios explicativos baseados nos resultados obtidos neste trabalho, e que poderão ser retomados, transformados ou mesmo revistos com novas pesquisas que permitam avaliar as diferentes formas de representação da variação linguística, bem como as possíveis regularidades e exceções que se observem em outras traduções literárias.

Agradecimentos: A Laura Belinelli de Jesus, ex-orientanda de Iniciação Científica (PróReitoria de Iniciação Científica da Unesp/PROPe), do Curso de Bacharelado em Letras com Habilitação de Tradutor (UNESP-IBILCE), pela obtenção parcial de certos dados desta pesquisa.

\section{REFERÊNCIAS BIBLIOGRÁFICAS}

BAGNO, M. Dicionário crítico de sociolinguística. São Paulo: Parábola, 2017.

. Não é errado falar assim! Em defesa do português brasileiro. $2^{\mathrm{a}}$. ed. São Paulo: Parábola, 2010.

BOURDIEU, P. A economia das trocas simbólicas. Tradução de Sergio Miceli et al. $7^{\mathrm{a}}$. edição. São Paulo: Perspectiva, 2011.

BRITTO, P. H. A tradução literária. Rio de Janeiro: Civilização Brasileira, 2012. p. 81-117. 
BRITTO, P.H.; LANDSBERG, D. As traduções de Huckleberry Finn à luz das normas de Toury. Tradução em Revista, n.20, vol. 2, p.2-16, 2015.

CHRISTIE, A. Assassinato no expresso oriente. Tradução de Petrucia Finkler. Porto Alegre, L\&PM, 2017. Cai o pano. Tradução de Bruno Alexander. Porto Alegre: L\&PM, 2015. 2014.

Um punhado de centeio. Tradução de Alexandre Boide. Porto Alegre: L\&PM, Morte na Praia. Tradução de R. Breunig. Porto Alegre: L\&PM, 2013.

DÓRIA, T. P. L; ALVES, V. R. O. Estudo da gramaticalização do termo/expressão tipo assim em "O diário de Tati”. Sociodialeto, n. 12, vol. 4, p.262-277, 2014. Disponível em: < http://www.sociodialeto.com.br/edicoes/17/31052014041317.pdf> Acesso em: 02 de março 2018.

EVEN-ZOHAR, I. Teoria dos polissistemas. Tradução de Luiz F. Marozo, Carlos Rizzon e Yanna Cunha. Translatio, n. 5, p.1-21, 2013. Disponível em:

<http://www.seer.ufrgs.br/translatio/article/viewFile/42899/27134>. Acesso em: 05 de janeiro de 2018.

FARACO, C. A. Norma culta brasileira: desatando alguns nós. São Paulo: Parábola, 2008.

HEMINGWAY, E. Contos: volume 2. Tradução de José J. Veiga. $5^{\text {a }}$ ed. Rio de Janeiro: Bertrand Brasil, 2015a.

Janeiro, 2015b.

Do outro lado do rio, entre as árvores. Tradução de José Geraldo Vieira. Rio de

. O sol também se levanta. Tradução de Berenice Xavier. Rio de Janeiro: Bertrand Brasil, 2015c.

Brasil, 2013.

Por quem dobram os sinos. Tradução de Luís Peazê. Rio de Janeiro: Bertrand

MORAIS, G. A representação do modelo de herói clássico na personagem feminina

Katniss Everdeen, de “Jogos vorazes". 2018. 218f. Dissertação (Mestrado em Letras).

Programa de Pós-Graduação em Letras - Universidade Estadual Paulista "Júlio de Mesquita Filho”, Instituto de Biociências, Letras e Ciências Exatas, 2018.

NEIVA, A. M. S. Native Son in Brazilian Portuguese with a study on dialects and translation: a nonlogocentric approach. 1995. 822f. Tese (Doutorado em Inglês) Department of English - Northern Illinois University, Dekalb, Illinois, 1995.

ROTH, P. Indignation. Boston, New York: Houghton Mifflin Company, 2008.

AMORIM. Contrastando marcas de oralidade em traduções de "alta literatura" e de "best-sellers de ficção popular": Ernest Hemingway e Agatha Christie

Belas Infiéis, v. 7, n. 1, p. 59-90, 2018. 
Indignação. Tradução de Jório Dauster. São Paulo: Companhia das Letras, 2013.

PANCAKE, B. D. J. Contos cortantes. Tradução de José J. Veiga. Rio de Janeiro: Bertrand Brasil, 1994.

PRADO HENRIQUE, H. M. Best-seller: a história de um gênero. Rio de Janeiro: Usina de Letras, 2010.

PRETI, D. (Org.). O discurso oral culto. 2a . edição. São Paulo: Humanitas, 1999.

SHAW, G. B. Pygmalion. Philadelphia: Pennsylvania State University, 2004.

Pigmaleão. Tradução de Millor Fernandes. Porto Alegre: L\&PM, 2005.

SODRÉ, M. Best-seller: a literatura de mercado. São Paulo: Ática, 1988.

TOURY, G. Descriptive translation studies and beyond. Revised edition.

Amsterdam/Philadelphia: John Benjamins Publishing Company, 2012.

TWAIN, M. The adventures of Huckleberry Finn. Feedbooks. E-book. Disponível em: <http://www.feedbooks.com/book/71/the-adventures-of-huckleberry-finn> Acesso em: $01 \mathrm{de}$ março 2018.

. As aventuras de Huckleberry Finn. Tradução de Rosaura Eichenberg. Porto Alegre: L\&PM, 2011.

VEIGA, J. J. Os cavalinhos de Platiplanto. 18 . ed. Rio de Janeiro: Bertrand, 1989.

A estranha máquina extraviada: contos. $4^{\mathrm{a}}$. ed. Rio de Janeiro: Civilização Brasileira, 1981.

Os pecados da tribo. $2^{\text {a }}$. ed. Rio de Janeiro: Civilização Brasileira, 1978.

WRIGHT, R. Native son. New York: Harper \& Rows, 1966.

\footnotetext{
${ }^{1}$ Departamento de Estudos Linguísticos e Literários - Instituto de Biociências, Letras e Ciências Exatas, campus de São José do Rio Preto, São Paulo.

${ }^{2}$ Os livros em questão foram escaneados e convertidos em arquivos do processador Word, deixando-se neles apenas os diálogos ou discursos diretos, excluindo-se, portanto, as passagens narrativas. Os arquivos foram em seguida, no formato txt, analisados quantitativamente no software gratuito de processamento linguístico AntConc, disponível para ser baixado no seguinte endereço: 〈http://www.laurenceanthony.net/software.html〉.

${ }^{3}$ Editora pertencente, desde 1996, ao grupo editorial Record.

${ }^{4}$ A variação diafásica diz respeito ao grau de maior ou menor informalidade em virtude do contexto situacional de uma fala, o que inclui aspectos como o tema sobre o qual se fala, a relação de maior ou menor intimidade entre falantes, o lugar onde ocorre o diálogo, bem como a maior ou menor assimetria de poder entre falantes (assimetria essa que pode ser tanto relacionada à relação hierárquica diferente quanto também à diferença de idade entre interlocutores). Comparativamente, a variação diastrática e a diatópica se relacionam menos com o contexto de enunciação do que com aspectos relativos ao falante propriamente dito. Assim, a variação diatópica se relaciona com as diferenças linguísticas oriundas da origem geográfica do falante, enquanto que a variação diastrática diz respeito às diferenças linguísticas derivadas da classe social do falante, bem como de seu maior ou menor grau de escolaridade. De maneira, geral esses três aspectos (variações diafásica, diatópica e diastrática) podem ser
} 
interseccionados ou se apresentar como um dado mais proeminente que o outro, especialmente quando se trata da representação da variação linguística em textos literários. Para informações mais detalhadas sobre esses aspectos da variação ver Bagno (2017, p. 83 e 89$)$.

${ }^{5}$ Os exemplos que ilustram as marcas de oralidade, nas duas tabelas desta seção, foram criadas pelo autor do artigo, e não extraídas dos romances analisados.

${ }^{6}$ Um dado a ser observado é a ocorrência destacada do pronome pessoal "te", especialmente no livro Por quem os sinos dobram, de Hemingway. Essa obra é a que apresenta o maior número de ocorrências desse pronome, mas isso tem uma explicação que não se restringe à busca de maior verossimilhança nos diálogos. Hemingway faz uso de "thee" (bem como de "thou") para se referir aos personagens espanhóis cujas falas são "traduzidas", para o inglês, com esses pronomes arcaicos. Na tradução para o português, o tradutor Luiz Peazê lança mão de pronomes de segunda pessoa, como "tu" (com verbos conjugados em segunda pessoa) e "te". Esse uso particular de "te", na tradução de Peazê, pode aparecer tanto em frases como "Não te faças de idiota [...]" (HEMINGWAY, 2013, p.234), que parece soar mais formal (já que a conjugação padrão do verbo em $2^{a}$ pessoa é mais formal, e menos comum, no Brasil), quanto em orações mais informais como "[...] estou contente por te ver" (HEMINGWAY, 2013, p. 185).

${ }^{7}$ Por motivos de ausência de espaço, as demais 05 marcas de oralidade ausentes nos romances serão exibidas mais adiante.

${ }^{8}$ Por motivos de ausência de espaço, as demais 15 marcas de oralidade ausentes nesses romances serão exibidas mais adiante.

${ }^{9}$ É claro que o número de páginas em si não pode ser tomado como garantia disso, já que um livro de 500 páginas pode conter muito menos diálogos, e mais trechos narrativos, do que um livro de 300 páginas que focalize a trama mais em torno de diálogos.

${ }^{10}$ Aqui não se observa o número de ocorrências de cada marca de oralidade em si, mas o número de tipos de marcas de oralidade que aparecem nas obras dentre as 45 analisadas.

${ }^{11}$ As informações sobre a $1^{\text {a }}$ edição do livro, publicada pela Civilização Brasileira, foram obtidas no blog: <http://naogostodeplagio.blogspot.com.br/2015/08/berenice-xavier.html>

12 Diversas marcas de oralidade, como por exemplo, o emprego de "ele" ou "ela" na função de objeto verbal e "se" condicional seguido de pretérito imperfeito, entre outros, podem ser observadas nos seguintes livros da autoria de José J. Veiga: Os pecados da tribo (VEIGA, 1978, p. 13; p. 36; p. 127); A estranha máquina extraviada (VEIGA, 1981, p. 86); Os cavalinhos de platiplanto (VEIGA, 1989, p. 4). Além disso, também é possível confirmar a aplicação de marcas de oralidade, por José J. Veiga, em uma tradução sua da obra Stories of Breece DJ. Pancake, uma coletânea de contos do escritor norte-americano Breece Pancake, publicada pela Bertrand Brasil (cf. PANCAKE, 1994, p. 29, p. 31, p.53, p.62, p.115).

${ }_{13}$ Por exemplo, Millor Fernandes traduz a seguinte diálogo: "THE MOTHER. How do you know that my son's name is Freddy, pray?/THE FLOWER GIRL. Ow, eez ye-ooa san, is e? Wal, fewd dan y' de-ooty bawmz a mather should, eed now bettern to spawl a pore gel's flahrzn than ran awy atbaht pyin. Will ye-oo py me f'them?" (SHAW, 2004, p. 9) por "MÃE: Como você sabe que meu filho se chama Frederico?/FLORISTA: Ah, A sinhora é a mãe du moço? Mãe boa, hein, qui insina êssis modus pru filho; bota as fror tudo no artolero i corri sim pargá. A madama vai pargá. A Madama vai pargá meus prejuízo?” (SHAW, 2005, p. 16).

${ }^{14}$ Eincheberg traduz o seguinte diálogo entre Huckleberry Finn e o escravo Jim: "“Well, are you rich?”/"No, but I ben rich wunst, and gwyne to be rich agin. Wunst I had foteen dollars, but I tuck to specalat' $n$ ', en got busted out." (TWAIN, s.d., p.41-42) por "—-Bem, ocê é rico?/ — Não, já fui rico uma veiz e vô sê rico de novo. Uma veiz eu tinha catorze dólar, mas comecei a ispeculá e perdi tudo" (TWAIN, 2011, p.58).

${ }^{15} \mathrm{O}$ autor deste artigo também analisou, em outro trabalho sob avaliação editorial, a ocorrência de marcas de oralidade em obra traduzida e publicada pela Companhia das Letras.

16 Toury (2012, p. 77) refere-se a três tipos de normas existentes em um (poli)sistema literário: "normas que dominam o centro e que, portanto, direcionam o comportamento tradutório direto daquilo que é reconhecido como sendo a tendência dominante; em convívio com resquícios de normas que já foram predominantes e que ainda se fazem presentes, mas enfraquecidas, tendo sido relegadas à margem, e rudimentos do que pode eventualmente se tornar um novo conjunto de normas". É possível que este último tipo de norma esteja se firmando com a maior abertura às marcas de oralidade, especialmente às diastráticas. Mais pesquisas, como esta e as de Brito e Landsberg (2015), no entanto, poderão confirmar essa tendência.

${ }^{17}$ Brito e Landsberg analisaram traduções da alta literatura (incluindo As aventuras de Huckleberry Finn), e não best-sellers de ficção popular.

${ }^{18}$ É claro que no caso do trecho em questão, extraído do livro Indignation, de Philip Roth, o tradutor, Jório Dauster, optou pela representação da variação linguística diafásica, não sendo, portanto, um exemplo prototípico da aplicação de normas tradutórias mais conservadoras como exposto acima.

AMORIM. Contrastando marcas de oralidade em traduções de "alta literatura" e de "best-sellers de ficção popular": Ernest Hemingway e Agatha Christie

Belas Infiéis, v. 7, n. 1, p. 59-90, 2018. 
${ }^{19}$ Essa questão é importante, porque, no passado (como, por exemplo, em traduções da primeira metade do século XX), a questão da variação linguística não era, necessariamente, um item que participava da avaliação positiva de uma tradução literária.

${ }^{20}$ Somente mais pesquisas poderão atestar, de maneira mais concreta, a natureza desse grau de favorecimento.

${ }^{21}$ Há que se perguntar: perigosa para quem?

${ }^{22}$ Exceção feita à Berenice Xavier, tradutora de $O$ sol também se levanta. Lembrando que essa tradução é a mais antiga dentre as quatro.

${ }^{23}$ Embora muitas formas linguísticas, de natureza diafásica, sejam empregadas - conscientemente ou não - até mesmo em jornais e em textos não literários disponíveis na internet, como confirma Bagno (2010), o que atesta a legitimidade de seu uso, entendemos que o seu emprego sistemático em textos literários traduzidos ainda encontra certa resistência, como observado no caso das traduções das obras de Agatha Christie e em outro trabalho de Amorim (sob avaliação) sobre a tradução de um best-seller de John Grisham.

${ }^{24}$ No caso, as traduções feitas por José J. Veiga (Contos volume 2), Luiz Peazê (Por quem os sinos dobram) e José Geraldo Vieira (Do outro lado do rio...). 